\author{
Корсікова Н.М. \\ кандидат економічних наук, доцент \\ E-mail:nkorsikova@ukr.net \\ Лємєшева В.В. \\ магістрант \\ кафедра менеджменту і логістики \\ Одеська національна академія харчових технологій \\ вул. Канатна, 112, м. Одеса, Україна, 65039 \\ E-mail:lemeshevavaleriya96@gmail.com
}

\title{
ДОСЛІДЖЕННЯ СУЧАСНИХ АЛЬТЕРНАТИВ ТА ПРИНЦИПІВ СТРАТЕГІЧНОГО УПРАВЛІННЯ ЯК ФАКТОРУ РОЗВИТКУ ПІДПРИЄМСТВ У СФЕРІ ГОТЕЛЬНИХ ПОСЛУГ
}

В статті обґрунтовано значення готельного бізнесу в економіці України та необхідність підвищення уваги менеджменту підприємств готельної сфрери до питання удосконалення стратегічного управління. Визначено що не вміння керівників застосовувати сучасний інструментарій стратегічного планування часто приводить їх компанії до стратегічної кризи, яка охоплює всі сфрери підприємства і призводить до падіння його показників ефективності. Відповідно авторами розглядаються зміст, особливості застосування та проблеми впровадження стратегічних альтернатив розвитку підприємств готельної сфери; систематизовано основні принципи впровадження стратегічних альтернатив розвитку закладів готельного господарства. Окрему увагу приділено визначенню поняття та факторів розвитку, як методологічного базису стратегічного розвитку, основних поточних проблем, які перешкоджають сьогодні розвитку вітчизняного готельного господарства. В роботі розглядаються особливості застосування альтернативних стратегічних рішень в діяльності закладів готельного бізнесу.

Ключові слова: стратегія, розвиток, принципи стратегічного планування, стратегічні альтернативи, готельні послуги, ефективність.

\section{This work is licensed under a Creative Commons Attribution 4.0 International License} http://creativecommons.org/licenses/by/4.0/

Постановка проблеми та зв'язок $з$ важливими науковими та практичними завданнями. Стратегічне управління вже давно визнано однією 3 фундаментальних складових успішного виживання у складній конкурентній боротьбі, але в практичній діяльності підприємства до сьогодні часто спостерігається відсутність стратегічного мислення, а саме: не беруться до уваги сучасні принципи планування стратегії; не проводиться аналіз можливостей та загроз підприємства на ринку; не здійснюється оцінка рівня розвитку підприємства, не беруться до уваги сучасні альтернативні напрями розвитку. Не вміння керівників застосовувати сучасний інструментарій стратегічного планування часто приводить їх компанії до стратегічної кризи, яка пов'язана 3 відсутністю чіткої або недостатньо розвинутої системи стратегічного управління. Поглиблення стратегічної кризи, в свою чергу, призводить до розвитку структурної (тактичної) кризи - кризи результатів: скороченню масштабів діяльності підприємства, зниження частки ринку, зменшення прибутків, скорочення чисельності персоналу тощо. Далі ланцюг кризи розгортається від хронічної неплатоспроможності - аж до банкрутства.

Отже, саме стратегічна криза стає акселератором подальших негативних процесів у розвитку як окремого підприємства, так і галузі в цілому. Відпо- відно в сучасній теорії стратегічного управління значну увагу приділено визначенню пріоритетних напрямів розвитку і в галузевому розрізі й в розрізі окремих суб'єктів господарювання.

Особливості географічного положення України, а саме розташування на перехресті транспортних та туристичних потоків з Свропи в Азію, наявність необхідних ресурсів для розвитку готельно інфраструктури: природних умов, історико-культурних ресурсів, трудових та матеріальних ресурсів, роблять особливо привабливою для бізнесу сферу готельних послуг. До того ж, навіть в сьогоднішніх складних умовах системної кризи, сфера готельних послуг залишається одним із самих сталих секторів економіки.

Значення готельного бізнесу обумовлено тим, що ця галузь спроможна дати поштовх для розвитку туризму, транспорту, роздрібної торгівлі, закладів громадського харчування, страхування, культури та мистецтва, архітектури та проектування, екскурсійного обслуговування, рекламної індустрії та багатьох інших сфер економіки будь-якої країни.

Саме тому стратегічний розвиток готельних господарств сьогодні відносять до числа важливих питань розвитку економіки України. Але у функціонуванні ринку готельних послуг в Україні виявлено ряд проблем, які пов'язані із складнощами переходу 
підприємств готельної сфери до сучасних умов господарювання, що змушує менеджмент підприємств в сфері готельних послуг приділяти підвищену увагу комплексу стратегічних заходів.

Аналіз останніх публікацій по проблемі. Питаннями теорії та практики стратегічного розвитку підприємств займалися відомі вітчизняні та зарубіжні вчені, передусім такі як: I. Ансофф, I.О. Бланк, В.О.Василенко, Х. Віссеи, В.М. Геєць, П. Друкер, М.М. Срмошенко, В.Г. Герасимчук, У. Кінг, Д. Кліланд, М.І. Круглов, Ф. Котлер, А.А. Мазаракі, Г. Мінцберг, Н.К. Моісеєва, А.П. Наливайко, В.В. Пастухова, М. Портер, А.А. Томпсон, Дж. Стрікленд, Н.М. Ушакова, А. Чендлер, А.В. Шегди, 3.С. Шершньова тощо.

Проблеми управління готельним господарством досліджено в наукових працях М. Бойко, О. Виноградової, С. Драгунцова, А. Ігнатьєв, С. Квартальнов, К. Ладиченко, Т. Марущака, Т. Ткаченко Д. Ушаков, та ін.

Узагальнюючі ї дослідження, можна стверджувати, що дотримання принципів стратегічного планування дозволяє досягти три найважливіших результати:

1) забезпечити системний потенціал для досягнення цілей підприємства, який буде складатися: по-перше, з фінансових, сировинних і людських ресурсів, що входять до підприємства; по-друге, з виробленої продукції (послуг), що затребуються ринком; по-третє, з сформованого позитивного іміджу підприємства;

2) забезпечити чутливість підприємства до змін зовнішнього середовища та його відповідну адаптацію до цих змін;

3) обгрунтувати вибір саме тих альтернативних напрямів розвитку, які б забезпечили формування конкурентних переваг компанії на конкурентному ринку.

Окрему увагу дослідники приділяють визначенню поняття та факторів розвитку, як методологічного базису стратегічного розвитку. Так на думку Гапоненко А. Л., Пакрухина А. П. «розвиток - рух уперед, формування нових рис, становлення нових структурних характеристик об'єкта, його еволюція, поліпшення, удосконалювання, прогрес, а також ріст і розширення» [1].

Дещо складнішим, але й, на наш погляд, більш актуальним є визначення розвитку, яке дає Раєвнєва О. В. Під розвитком підприємства вона розуміє унікальний процес трансформації відкритої системи в просторі і часі, який характеризується перманентною зміною глобальних цілей існування системи шляхом формування нової дисипативної структури i переводом його в новий атрактор (одна 3 альтернативних траєкторій розвитку підприємства) функціонування [5].

Саме зміна глобальних цілей і формування альтернативних траєкторій розвитку можуть забезпечити компаніям , які діють на ринку готельних послуг, не тільки поточний розвиток, а й стратегічні конкурентні переваги у майбутньому.
Формулювання цілей дослідження. Метою дослідження $є$ розробка теоретико-практичних рекомендацій щодо застосування сучасних принципів та альтернатив стратегічного планування, як фактору забезпечення сталого розвитку підприємств сфери готельних послуг України.

Виклад основних результатів та їх обгрунтування. Насамперед слід зазначити, що особливості менеджменту організацій готельного господарства пов' язані з особливостями ринку послуг і специфікою послуг як товару, а саме:

- послуга не існує до ії надання; значеності;

- послугам властивий високий ступінь неви-

- нездатність послуг до зберігання;

- мінливість якості послуги в залежності від багатьох факторів, як внутрішніх, так і зовнішніх;

- невід ємною частиною послуг є люди, які їх надають тощо.

Ці особливості значно ускладнюють процес забезпечення довгострокових переваг на ринку послуг без застосування сучасних ефективних технологій управління.

До того ж політичні події минулих років (2014-2017 рр.) негативним чином відобразилися на динаміці кількісних показників діяльності готельних закладів України, про що свідчать дані статистики (таблиця 1) [3].

32011 по 2013 роки включно спостерігалась позитивна динаміка через збільшення кількості колективних засобів розміщування - за цей період їх кількість зросла майже на 9\%. Але вже з 2014 року простежується спад цього процесу - загальна кількість засобів для розміщення туристів зменшилась на $36 \%$. В першу чергу це обумовлено недостатнім потоком туристів та низьким рівнем завантаженості готелів (середня завантаженість у готелях світу становить 65-75\%; в Україні цей показник -50\% [4]). Не останнє місце у формуванні такого стану відіграє зміна структури туристичних потоків в Україні. Так, за даними статистичних органів, 88\% іноземних відвідувачів України мають суто приватну мету приїзду і лише 8 \% здійснюють організовані тури, а 4\% знаходяться у службовій поїздці. Отже, більшість іноземних відвідувачів не потребують готелів, особливо VIP-класу.

Серед основних поточних проблем, які перешкоджають сьогодні розвитку вітчизняного готельного господарства, можна виділити наступні:

- невідповідність цін рівню якості готельних послуг;

- недостатня кількість та неналежний рівень підготовки кадрів для готельного господарства;

- в умовах ринкової економіки все актуальнішою стає проблема інформаційного забезпечення підприємств готельного бізнесу;

- недостатня увага маркетингу тощо.

Особливістю стратегії в складних умовах, в яких опинилася готельна галузь, є іiі чітка орієнтація на виявлення і запобігання причинам кризи, а також на правильні дії підприємства в кризових ситуаціях. 
Таблиця 1

Кількість колективних засобів розміщування в Україні [4]

\begin{tabular}{|c|c|c|c|c|c|c|c|c|c|}
\hline \multirow[b]{3}{*}{ Рік } & \multicolumn{3}{|c|}{$\begin{array}{l}\text { Кількість колективних } \\
\text { засобів розміщування }\end{array}$} & \multicolumn{3}{|c|}{ Кількість місць,тис. } & \multicolumn{3}{|c|}{ Кількість розміщених,тис. } \\
\hline & \multirow[b]{2}{*}{$\begin{array}{l}0 \\
0 \\
0 \\
0 \\
0\end{array}$} & \multicolumn{2}{|c|}{ у тому числі } & \multirow[b]{2}{*}{$\begin{array}{l}0 \\
0 \\
0 \\
0 \\
\lambda\end{array}$} & \multicolumn{2}{|c|}{ у тому числі } & \multirow[b]{2}{*}{$\begin{array}{l}0 \\
0 \\
0 \\
0 \\
\lambda\end{array}$} & \multicolumn{2}{|c|}{ у тому числі } \\
\hline & & 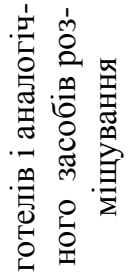 & 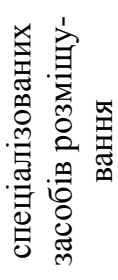 & & 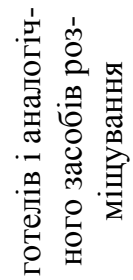 & 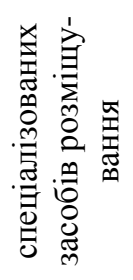 & & 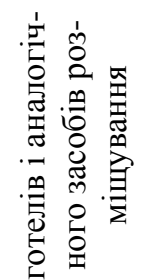 & 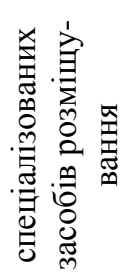 \\
\hline 2011 & 5882 & 3162 & 2720 & 567,3 & 154,2 & 413,1 & 7426,9 & 4656,8 & 2770,1 \\
\hline 2012 & 6041 & 3144 & 2897 & 583,4 & 162,8 & 420,6 & 7887,4 & 4983,9 & 2903,5 \\
\hline 2013 & 6411 & 3582 & 2829 & 586,6 & 179,1 & 407,5 & 8303,1 & 5467,8 & 2835,3 \\
\hline 2014 & 4572 & 2644 & 1928 & 406,0 & 135,5 & 270,5 & 5423,9 & 3814,2 & 1609,7 \\
\hline 2015 & 4341 & 2478 & 1863 & 402,6 & 132,5 & 270,1 & 5779,9 & 4297,2 & 1482,7 \\
\hline 2016 & 4256 & 2534 & 1722 & 375,6 & 135,9 & 239,7 & 6544,8 & 5037,1 & 1507,7 \\
\hline 2017 & 4115 & 2474 & 1641 & 359 & 133,4 & 225,6 & 6661,2 & 5135,2 & 1526,0 \\
\hline
\end{tabular}

Зміст стратегічного планування в умовах фактично кризи, перш за все, повинен зосереджуватися на наступних елементах:

1. Сфера діяльності та основні напрями iї розвитку. Потрібно виділити особливості сегменту ринку, який займає підприємство, для його ефективного аналізу і можливості запобігання кризам.

2. Цілі діяльності. Для антикризового управління найбільший інтерес представляють цілі в довгостроковому періоді, оскільки саме від них залежить напрям розвитку організації. Визначення цілей визначає всі подальші дії з розробки стратегії.

3. Визначення методів і форм досягнення цілей. Здійснюється пошук і вибір альтернатив. Від того, якою буде програма досягнення результату, залежить все функціонування організації. Важливо розглядати ці методи 3 погляду безпеки для діяльності організації і доцільності по відношенню до наявних ресурсів.

4. Кадрова політика. Визначає внутрішню структуру персоналу організації, рівень взаємин між керівництвом, персоналом і клієнтами.

5. Організація процесу надання послуг:

- розподіл ресурсів;

- оцінка технічної бази;

- забезпечення всіх сфер діяльності сучасними технологічними рішеннями тощо.

6. Оцінка внутрішнього і зовнішнього середовища бізнесу. Дослідження середовища бізнесу має першорядне значення як для готелів, що тільки виходять на ринок, так і для готелів, що переглядають свою стратегію у зв'язку з кризою або по інших причинах.

7. Розробка маркетингової програми. При оцінці споживачів необхідно враховувати безліч чинників і особливостей:

1) демографічні характеристики: віковий контингент, стать, сферу діяльності;

2) соціально-психологічні характеристики: смаки, переваги, інтереси клієнтів;

3) ступінь поінформованості споживача про ринок готельних послуг в цілому, асортимент наданих послуг тощо;

4) чутливість споживачів до цін на послуги.

Після діагностики середовища готельного бізнесу розробляється сама стратегія. Цей процес супроводжується також переглядом місії і установок компанії.

Узагальнення досвіду «виживання» вітчизняних і зарубіжних закладів готельного бізнесу дозволило визначити деякі особливості застосування альтернативних стратегічних рішень в діяльності закладів готельного бізнесу.

1. Стратегія мінімізації витрат. Як правило, основним джерелом мінімізації витрат є встановлення оптимального значення обсягу виробництва (виробничий ефект масштабу) просування і збуту (маркетинговий ефект масштабу). Тому лише відносно крупні організації можуть дістати доступ до переваг ефектів масштабу. Значно впливати на параметри стратегічної рівня обсягу виробництва можуть і технологічні інновації. Як радикальні. Так і поліпшуючі. В готельній галузі реалізація такої стратегії може бути пов'язане 3 наданням стандартного набору послуг за мінімальною собівартістю, а відповідно і ціною їх надання. 3 одного боку, це дає шанс на підвищення рівня рентабельності послуг, а з іншого - зацікавлювати відвідувачів більш низькою ціною у довгостроковому періоді.

2. Стратегія диференціації. У виробничій сфері заснована на виробництві широкої номенклатури товарів одного функціонального призначення i дозволяє організації обслуговувати більшу кількість споживачів з різними потребами. В готельній сфері, як і виробничій, диференціація може бути розділена на два види. Перший - горизонтальна, при якій ціна залишається приблизно однаковою, і середній рівень доходу споживачів однаковий. Наприклад, готель 
може запропонувати гостю номери, оформлені за різною тематикою, стилем тощо. Другий вид - вертикальна, при якій і ціни, і середній рівень доходу спожи-

Актуальним «інструментом» реалізації такої стратегії $є$ зрощування готельного бізнесу 3 іншими сферами обслуговування: ресторанним бізнесом, розважальними і спортивними комплексами тощо.

Така стратегія дозволяє організації отримувати доступ до різних сегментів клієнтів, що збільшує обсяг реалізації, але, одночасно, підвищує собівартість послуг.

3. Стратегія сфокусованої ніші (фокусування). Припускає обслуговування вузького сегменту споживачів, що характеризується особливими потребами, а відповідно захоплення тих ніш на ринку, що не викликають інтерес у інших конкурентів, чи тимчасово не зайняті ними. Так дотримуючись стратегії фокусування, готель може концентрувати свою увагу на колі споживачів, що відпочивають сім'ями (так 3'являються готелі сімейного типу, з спеціалізованим дитячим харчуванням, аніматорами, аквапарками, сімейними номерами, відсутністю гучних нічних вечірок тощо) чи на певному географічному сегменті (готелі на екзотичних, майже безлюдних островах, у колишніх в'язницях тощо); актуальною є екологічна направленість готелів тощо.

Але слід мати на увазі, що найбільш успішно дана стратегія може реалізовуватися тоді, коли:

- існують достатньо великі групи споживачів, чиї потреби в товарі із заданим функціональним призначенням значно відрізняються від середньостатистичних; вачів різний. Наприклад, готель повинен забезпечити відвідувачам можливість вибору номерів різного класу розміщення, оснащення, сервісу тощо.

- існують відносно невеликі групи клієнтів, що мають нестандартні потреби, і потреби даних груп споживачів не задоволені в належній мірі.

Одна з основних складностей реалізації даної стратегії пов'язана 3 тим що, падіння цін на ринку стандартних послуг може призвести до переходу споживачів цільового сегменту до загального ринку;

4. Стратегія інновацій. Припускає отримання конкурентних переваг за допомогою створення принципово нових товарів, послуг, або задоволення існуючих потреб новим способом. Організації, що вибрали дану стратегію, прагнуть сформувати конкурентну перевагу за рахунок здійснення радикальних інновацій в різних сферах своєї діяльності.

Інноваційна стратегія в готельному бізнесі не повинна зводитися до випуску нових послуг або до використання прогресивних інформаційних технологій(наприклад бронювання місць в готелях), але й такх нововведень, які торкаються сфери управління (фінансами, оперативної діяльністю, персоналом тощо). Саме одночасне впровадження різних типів інновацій забезпечує максимальний економічний ефект.

Остаточний вибір стратегічного напряму розвитку конкретного закладу повинен відповідати не тільки потенціалу і можливостям фірми (персоналу, фінансовим ресурсам, існуючий структурі тощо) але й умовам виконання низькі базових принципових положень (таблиця 2).

Таблиця 2

\section{Принципи управління стратегічним розвитком *}

\begin{tabular}{|c|c|c|}
\hline $\begin{array}{c}\text { Назва } \\
\text { принципу }\end{array}$ & Сутність принципу & Приклад реалізації принципу \\
\hline $\begin{array}{l}\text { Принцип } \\
\text { рефлексії }\end{array}$ & $\begin{array}{l}\text { Відображає необхідність розуміння того, як } \\
\text { сприймають цінності, інтереси особи, що ухва- } \\
\text { лює рішення, інші виконавці з даної системи. } \\
\text { Крім того, необхідно враховувати інтереси су- } \\
\text { б'єктів зовнішнього середовища. }\end{array}$ & $\begin{array}{l}\text { У керівника та працівників наявна спільна } \\
\text { мета, що не суперечить їхнім інтересам. }\end{array}$ \\
\hline $\begin{array}{l}\text { Принцип } \\
\text { самоорганізації }\end{array}$ & $\begin{array}{l}\text { Грунтується на флуктаційній взаємодії його } \\
\text { складових. Під флуктуацією розуміємо випад- } \\
\text { кове відхилення стійкого значення величини від } \\
\text { iї середнього значення, обумовленого хаотич- } \\
\text { ним рухом частин системи. }\end{array}$ & $\begin{array}{l}\text { Побудова алгоритму дій працівників у тій } \\
\text { чи іншій ситуації без попереднього їі обго- } \\
\text { ворення, а миттєвого та адекватного реагу- } \\
\text { вання на неї. }\end{array}$ \\
\hline $\begin{array}{l}\text { Принцип } \\
\text { обмеженої ра- } \\
\text { ціональності }\end{array}$ & $\begin{array}{l}\text { Менеджер прагне не до максимального, а до } \\
\text { задовільного результату. Йому можуть бути } \\
\text { відомі не всі альтернативи: досить, щоб він був } \\
\text { обізнаний хоча б про декілька прийнятних варі- } \\
\text { антів рішення. }\end{array}$ & $\begin{array}{l}\text { Вироблення рішень на основі прогнозної } \\
\text { інформації і знань про тенденції зміни еко- } \\
\text { номічних інтересів елементів, складових } \\
\text { системи і компонентів зовнішнього сере- } \\
\text { довища. Їх корегування по мірі надхо- } \\
\text { дження нових даних до моменту початку } \\
\text { реалізації рішення і подальшої адаптації в } \\
\text { ході реалізації }\end{array}$ \\
\hline $\begin{array}{l}\text { Принцип } \\
\text { диверсифікації }\end{array}$ & $\begin{array}{l}\text { Одночасний розвиток, поєднання різноманіт- } \\
\text { них видів діяльності, інший варіант - концент- } \\
\text { рація різноманітних видів діяльності }\end{array}$ & $\begin{array}{l}\text { Раціональне використання ресурсів шля- } \\
\text { хом повнішого залучення у виробничий } \\
\text { оборот всіх наявних ресурсів підприємства. } \\
3 \text { іншої сторони - ефективний розподіл ре- } \\
\text { сурсів між альтернативними варіантами } \\
\text { використання. }\end{array}$ \\
\hline
\end{tabular}


Продовження табл.2

\begin{tabular}{|l|l|l|}
\hline \multicolumn{1}{|c|}{$\begin{array}{c}\text { Назва } \\
\text { принципу }\end{array}$} & \multicolumn{1}{|c|}{ Сутність принципу } & \multicolumn{1}{|c|}{ Приклад реалізації принципу } \\
\hline $\begin{array}{l}\text { Принцип } \\
\text { резервування } \\
\text { ресурсів }\end{array}$ & $\begin{array}{l}\text { Потреба в ресурсах не залежить від ринкового } \\
\text { положення підприємства, швидше їі ресурсний } \\
\text { потенціал зумовлює успішне положення його } \\
\text { на ринку. }\end{array}$ & $\begin{array}{l}\text { Наявність достатнього об'єму матеріаль- } \\
\text { них та трудових ресурсів не зважаючи на } \\
\text { сезонність роботи підприємства. }\end{array}$ \\
\hline $\begin{array}{l}\text { Принцип } \\
\text { безперервної } \\
\text { адаптації }\end{array}$ & $\begin{array}{l}\text { Стійкість реалізується через нестійкість, а в } \\
\text { подоланні нестійкості реалізується стійкість. } \\
\text { Таким чином, існує певна точка рівноваги, в } \\
\text { якій необхідно підтримувати стан системи, для } \\
\text { чого використовується управління в реальному } \\
\text { масштабі часу. }\end{array}$ & $\begin{array}{l}\text { Своєчасна здатність реагувати на зміну } \\
\text { падження інновацій. }\end{array}$ \\
\hline
\end{tabular}

*Складено авторами на основі джерел [8]

Оцінка ефективності обраної стратегії повинна проводитися за наступними показниками:

- економічний ефект - можливість збільшення маси прибутку, строк окупності інвестицій;

- соціальний ефект - підвищення рівня культури обслуговування та задоволеності клієнтів, поліпшення умов і привабливості праці, іміджу і репутації готелю;

- техніко-технологічний ефект - підвищення техніко-технологічного рівня оснащення як номерів готелю, так і засобів праці на різних щаблях технологічного процесу та системи управлінні готелю.
Висновки та перспективи подальших досліджень. В умовах високого рівня турбулентності зовнішнього середовища, коли воно майже не передбачуване і не залежить від впливу підприємства, та одночасного посилення конкуренції, ігнорування ним стратегічного аспекту управління може спричинити для нього катастрофічні наслідки. Саме тому готелі змушені шукати нові шляхи підвищення своєї привабливості, що не можливо без урахування особливостей, переваг та ризиків впровадження різних альтернативних стратегічних рішень та принципів їх впровадження.

\section{Література}

1.Байлик С.І. Готельне господарство. Проблеми, перспективи, сертифікація : навч. посібник. Київ : Дакор, 2006, 288 с.

2.Гапоненко А.Л. Панкрухин А.П. Стратегическое управление: учебник. Москва: Омега, 2004, 472 с.

3..Горіна Г.О. Особливості сучасного розвитку готельної індустрії України // Вісник Сумського державного університету. 2010. № 2. С.12-13

4.Державна служба статистики України [Електронний ресурс] URL: http://www.ukrstat.gov.ua (дата звернення 11.10.2018).

5.Журавльова С.М. Стратегія інноваційної діяльності на підприємствах готельного господарства // Економіка. Управління. Інновації. 2012. №2. С.8.

6.Корнева Д.А. Особливості розвитку туристичної інфраструктури в Україні // Вісник ДІТБ. 2011. № 15. C. $174-180$

7.Раєвнєва О. В. Управління розвитком підприємства: методологія, механізми, моделі: монографія. Харків: ВД«ІНЖЕК», 2006, 496с.

8.Томпсон А.А., Стрикленд А.Дж. Стратегический менеджмент. Искусство разработки и реализации стратегий: учебник для вузов. Москва: Банки и биржи, ЮНИТИ, 1998, 576 с.

9.Управління сучасним готельним комплексом: навч. посіб. /Мунін Г.Б.та ін. Київ: Ліра-К, 2005.520 с.

10.Черкасова T.І. Стратегія та контроль інноваційного розвитку підприємства: монографія. Одеса: Астропринт, 2010, $310 \mathrm{c}$.

Стаття надійшла 22.10.2018

Стаття прийнята до друку 5.11.2018

Доступно в мережі Internet 29.12.2018 


\author{
Корсикова Н.Н. \\ кандидат экономических наук, доцент \\ E-mail:nkorsikova@ukr.net \\ Лемешева В.В. \\ магистрант \\ кафедра менеджмента и логистики \\ Одесская национальная академия пищевых технологий \\ Ул. Канатная,112,г. Одесса, Украина, 65039 \\ E-mail:lemeshevavaleriya96@gmail.com
}

\title{
ИССЛЕДОВАНИЕ СОВРЕМЕННЫХ АЛЬТЕРНАТИВ И ПРИНЦИПОВ СТРАТЕГИЧЕСКОГО УПРАВЛЕНИЯ КАК ФАКТОРА РАЗВИТИЯ ПРЕДПРИЯТИЙ В СФЕРЕ ГОСТИНИЧНЫХ УСЛУГ
}

В статье обосновано значение гостиничного бизнеса в экономике Украины и необходимость повышения внимания менеджмента предприятий гостиничной сферы вопросу совершенствования стратегического управления. Определено, что не умение руководителей применять современный инструментарий стратегического планирования часто приводит их компании к стратегическому кризису острому, глубокому кризису, затрагивающему все сферы предприятия и приводящему к ухудшению показателей его эффективности.

Соответственно авторами рассматриваются содержание, особенности применения и проблемы внедрения стратегических альтернатив развития предприятий в гостиничной сфере. Особое внимание уделено определению понятия и фракторов развития, как методологического базиса стратегического развития, основных текущих проблем, препятствующих сегодня развитию отечественного гостиничного хозяйства; выделено те элементы стратегического планирования, на которых необходимо сосредоточиться прежде всего: выделить особенности сегмента рынка, сформулировать долгосрочные цели, определиться с возможными альтернативами и инструментами достижения целей, уделить особое внимание кадровым вопросам и разработке маркетинговой программе.

В работе рассматриваются особенности применения и преимущества реализации альтернативных стратегических решений в деятельности учреждений гостиничного бизнеса: стратегии минимизации расходов, стратегии диффференциации, стратегии фокусирования и стратегии инноваций.

Внимание уделено формированию системы принципов, реализация которых позволить повысить эфффективность стратегического планирования в гостиничной отрасли, а также вопросу оценке эфффективности выбранной стратегии.

Ключевые слова: стратегия, развитие, принципы стратегического планирования, стратегические альтернативы, гостиничный бизнес, эффрективность.

\section{Korsikova N.}

Ph.D., Associate Professor

E-mail:nkorsikova@ukr.net

Liemiesheva V.

Undergraduate

Department of Management and Logistics

Odessa National Academy of Food Technologies

Kanatna str., 112, Odesa, Ukraine, 65039

E-mail:lemeshevavaleriya96@gmail.com

\section{RESEARCH OF THE MODERN ALTERNATIVES AND PRINCIPLES OF THE STRATEGIC MANAGEMENT AS A FACTOR OF DEVELOPMENT OF ENTERPRISES IN THE FIELD OF HOTEL SERVICES}

The article substantiates the importance of the hotel business in the economy of Ukraine and the necessity of the increase of the attention of the hotel industry management to the issue of improving of strategic management. It has been determined that the lack of ability of managers to apply modern tools of strategic planning often leads their companies to a strategic crisis - an acute, deep crisis affecting all areas of the enterprise and leading to worsening of its efficiency indicators.

Accordingly, the authors consider the table of contents, peculiarities of application and problems of the introduction of strategic alternatives to the development of enterprises of the hotel industry. Particular 
attention is paid to the definition of the concept and development factors, as a methodological basis for strategic development, the main current problems that today prevent the development of the domestic hotel industry; have been emphasized those elements of strategic planning, which are necessary to focus on first of all: to highlight the features of the market segment, formulate long-term goals, determine possible alternatives and tools to achieve the goals, pay special attention to personnel issues and development of a marketing program.

In this work the features of the use and advantages of implementing have been considered of alternative strategic decisions in the activities of hotel business institutions: strategies to minimize costs, differentiation strategies, focus strategies and innovation strategies.

Attention is paid to the formation of a system of principles, the implementation of which will allow to improve the effectiveness of strategic planning in the hotel industry, as well as the issue of evaluating the effectiveness of the chosen strategy.

Key words: strategy, development, principles of strategic planning, strategic alternatives, hotel business, efficiency.

\section{References}

1. Bailyk, S. I. (2006). Gotel'ne gospodarstvo. Problemi, perspektivi, sertifikaciâ. Kï̈v: Dakor.

2. Haponenko, A. L., \& Pankrukhyn, A. P. (2004). Strategičeskoe upravlenie. Moskva: Omega.

3. Horina, H. O. (2010). Osoblivostì sučasnogo rozvitku gotel'noï ìndustriï Ukraïni. Vissnik Sums'kogo Deržavnogo Universitetu, (2), 12-13.

4. Deržavna služba statistiki Ukraïni. (2018). Retrieved October 11, 2018, from http://www.ukrstat.gov.ua

5. Zhuravlova, S. M. (2012). Strategiâ ìnnovacijnoï diâl'nostì na pìdpriêmstvah gotel'nogo gospodarstva. Ekonomika. Upravlìnnâ. İnnovaciï., (2), 8.

6. Korneva, D. A. (2011). Osoblivostì rozvitku turističnoï ìnfrastrukturi v Ukraïnì. Vissnik DİTB, (15), 174-180. VD «ÌNŽEK».

7. Raievnieva, O. V. (2006). Upravlìnnâ rozvitkom pidpriêmstva: Metodologîa, mehanizmi, modelì. Harkìv:

8. Tompson, A. A., \& Striklend, A. Dzh. (1998). Strategičeskij menedžment. Iskusstvo razrabotki i realizacii strategij. Moskva: Banki i birži, ÛNITI.

9. Munin, H. B. (2005). Upravlinnâ sučasnim gotel'nim kompleksom. Kiïv: Lìra-K.

10. Cherkasova, T. I. (2010). Strategiâ ta kontrol' innovacijnnogo rozvitku pìdpriêmstva. Odesa: Astroprint.

Received 22 October 2018

Approved 5 November 2018

Available in Internet 29.12.2018

Цитування згідно ДСТУ 8302:2015

Корсікова Н.М., Лємєшева В.В. Дослідження сучасних альтернатив та принципів стратегічного управління як фактору розвитку підприємств у сфері готельних послуг // Економіка харчової промисловості. 2018. Т.10, вип. 4. C. $95-101$.

doi: $10.15673 /$ fie.v10i4.1137

Cite as APA style citation

Korsikova N., \& Liemiesheva V. (2018). Research of the modern alternatives and principles of the strategic management as a factor of development of enterprises in the field of hotel services. Food Industry Economics, 10(4), 95-101; doi: $10.15673 /$ fie.v10i4.1137 